\title{
Research on Photovoltaic Power Generation Efficiency Detection \& Case Analysis
}

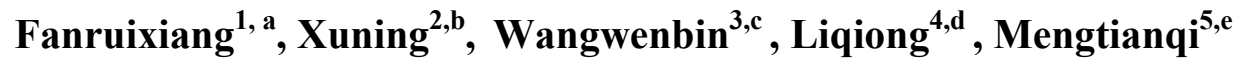 \\ $1,2,3,4,5$ State Power Research Institute of Jiangxi electric power company, Beijing,100094 China \\ a,b,c,d,eluow@enacs.com.cn
}

Keywords: Photovoltaic Power Generation; Detection Methods; Component Conversion Efficiency; Inverter Efficiency; Photovoltaic Power Plant Efficiency

\begin{abstract}
As the photovoltaic industry increasingly matured in China, photovoltaic power generation efficiency has received extensive attention. Because the level of photovoltaic power generation efficiency directly affects the efficiency of photovoltaic power generation, improving the efficiency of photovoltaic power generation is becoming a key factor in the profitability of photovoltaic power plants. It is imminent to find effective efficiency detection method. Based on this, the principle of testing the key equipment efficiency of PV power plant is mainly described and a case analysis is given in this paper, which could provide an effective reference for the efficiency test of PV power plant.
\end{abstract}

\section{Introduction}

With the increasing proportion of photovoltaic power generation in the field of power generation, the photovoltaic power generation efficiency has aroused widespread concern in the industry. The efficiency of PV power generation reflects the comprehensive power generation capacity of PV power plants. The efficiency of power plant is mainly determined by the conversion efficiency of PV modules, inverter efficiency, line loss and other factors. Started with the key factors that affect the efficiency of the power station, the conversion efficiency of the PV module, the efficiency of the inverter, the overall efficiency of the power plant and its case analysis will be detailed introduced in this paper.

\section{Test Method on Power Generation Efficiency of Photovoltaic Power Plants}

Test Method on Conversion Efficiency of Photovoltaic Modules. The PV module conversion efficiency can be defined as the ratio of the actual output power of the component to the power of the component producing at the standard light intensity. In order to ensure the validity of the data, the PV modules have been extracted into three pieces to test and the extracted components are tested twice in succession. Test schematic diagram is shown in Figure 1. The formula is as follows:

$$
\text { TJRO }=(\text { VOC-k } \cdot \text { VOC_STC }) / \beta+25
$$

Where TJRO is the component battery junction temperature, $\beta$ is the measured as the temperature coefficient of PV component, $\mathrm{K}$ is the ratio of irradiance to $1000 \mathrm{~W} / \mathrm{m} 2$. The value of $\mathrm{K}$ is shown in Table 1.

Correction temperature:

$$
\mathrm{TO}=\mathrm{TSM}+\mathrm{dT}+\mathrm{TJRO}-\mathrm{TSR}
$$

Where TSM is the center temperature of the backplane surface of the measured PV module, TSM is the non-center temperature of the backplane, $\mathrm{dT}=\mathrm{TSA}-\mathrm{TSM}$, TSA is the back surface temperature of 
the measured PV module in its array, TSM is the backplane surface temperature of any non-central assembly in the PV array. The maximum operating current in nominal state is corrected as:

$$
\text { IMPP_STC=IMPP_TEST+IMPP_TEST }(1000 / G-1)+\alpha \cdot I M P P \_T E S T / 100
$$

Where IMPP_TEST is the maximum operating current test value, $\mathrm{G}$ is the irradiance test value, and $\alpha$ is the current temperature coefficient of the measured PV module. The maximum operating current in nominal state is corrected as:

$$
\text { VMPP_STC=VMPP_TEST }+\beta \cdot V M P P \_T E S T(25-T 0) / 100
$$

Where VMPP_TEST is the maximum operating voltage test value. Fixed maximum operating power in nominal state:

$$
\text { PMPP_STC=VMPP_STC·IMPP_STC }
$$

The efficiency of the components of the PV module is measured as:

$$
\eta \text { out=PMPP_STC } / 1000 \cdot \text { Aout }
$$

Where A is the nominal total area of the tested PV module. (Unit: $\mathrm{m} 2$ )

Table $1 \mathrm{k}$ and irradiance ratio coefficient table

\begin{tabular}{|l|l|}
\hline $\mathrm{K}$ & Irradiation Interval $/(\mathrm{W} \cdot \mathrm{m}-2)$ \\
\hline 1.000 & $\mathrm{G}>1000$ \\
\hline 0.996 & $900<\mathrm{G}<1000$ \\
\hline $800<\mathrm{G}<900$ & \\
\hline 0.983 & $700<\mathrm{G}<800$ \\
\hline
\end{tabular}

Table 2 Photoelectric Conversion Efficiency of Common Solar Cells

\begin{tabular}{|l|l|l|}
\hline \multirow{2}{*}{ Species } & Material & $\begin{array}{l}\text { Photoelectric Conversion } \\
\text { Efficiency (\%) }\end{array}$ \\
\hline $\begin{array}{l}\text { Crystalline Silicon Solar } \\
\text { Cells }\end{array}$ & Monocrystalline Silicon & $14 \sim 25$ \\
\cline { 2 - 3 } & Polysilicon & $11 \sim 21$ \\
\hline \multirow{4}{*}{$\begin{array}{l}\text { Thin Film Solar Energy } \\
\text { Battery }\end{array}$} & Amorphous Silicon & $8 \sim 13$ \\
\cline { 2 - 3 } & Cadmium Telluride & $10 \sim 15$ \\
\cline { 2 - 3 } & $\begin{array}{l}\text { Copper Indium Gallium } \\
\text { Selenium }\end{array}$ & $10 \sim 15.5$ \\
\cline { 2 - 3 } & Gallium Arsenide & $20 \sim 40$ \\
\hline
\end{tabular}

Photovoltaic Inverter Efficiency Test Method. The inverter efficiency is the ratio of the AC output power of the PV inverter to the DC input power. This is:

$$
\eta=\text { Pout } / \text { Pin }
$$

Where Pout is the AC output power of the PV inverter, Pin is the DC input power of the PV inverter. Inverter efficiency test schematic diagram is shown in Figure 2. The efficiency tester is accessed to the inverter DC side and AC side and the power range efficiency is measured respectively (each 10\% power interval to take an efficiency value). And then the distribution trend of full power segment efficiency is obtained. 


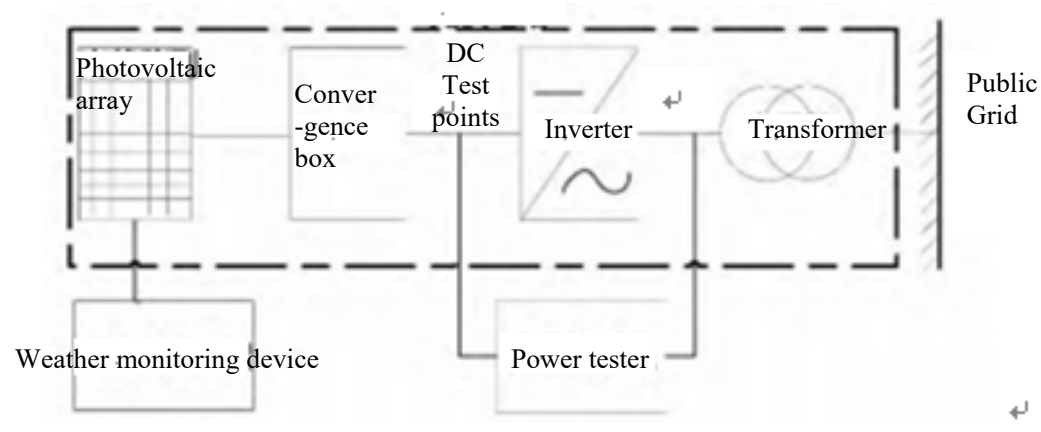

Figure 1 Schematic Diagram of Inverter Efficiency Test

Hardware \& Software Design of Photovoltaic Power Generation. The hardware circuit mainly includes the controller module, the sun light detection module, the steering control module, the ambient light detection module and the communication module (Fig. 4). MK60DN512 microcontroller of Freescale Semiconductor ARM Cortex-M4 core is used as the Master Controller. The processor integrates a high-precision A / D converter interface and PWM interface. Therefore linear CCD data acquisition and servo control could be easily achieved without external expansion. Linear CCD selected LORAL Company's CCD111 module which contains 256 linear array of photodiodes. Data reading and processing of CCD111 and TSL2561, angle data output and other work could be completed in the timer Interrupt service subroutine.

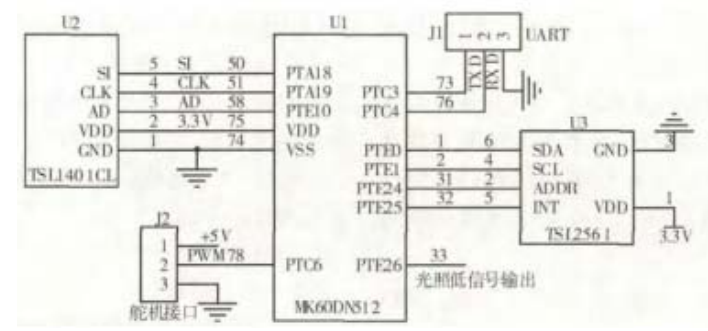

Figure 2 Schematic Diagram of the System Circuit

Photovoltaic Power Plant Efficiency Test Method. Photovoltaic power plant efficiency test schematic diagram is shown in Figure 3. Meteorological parameters acquisition module is used to complete the PV square radiometry, temperature and the collection of other meteorological parameters. Calculation of the photovoltaic power plants efficiency is defined in the following two ways. The photovoltaic power plant system power generation efficiency is the ratio of the total power generation of photovoltaic power plants in a certain time to all the theoretical power generation of photovoltaic power plant. Which is: 


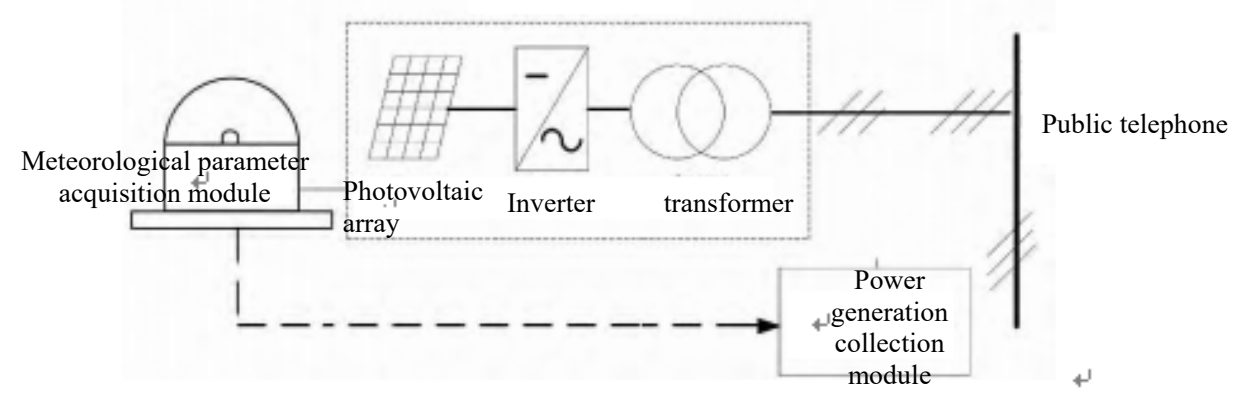

Figure 3 Schematic Diagram of Photovoltaic Power Plant Efficiency Test

$\eta$ out, $\quad \tau=$ Eout,$\quad \tau /(\tau \mathrm{r} \times \mathrm{Aa} \times \Sigma \tau \mathrm{GI})$

Where Eout, $\tau$ is the total output energy of the photovoltaic power generation system, Aa is the total area of the square matrix, $\tau \mathrm{r}$ is the data recording time interval, and GI is the total irradiance of the square plane.

Definition 2: The standard performance ratio (performanceratio) is used to reflect the power generation efficiency of photovoltaic power plants, which is expressed as the ratio of the number of hours of photovoltaic equivalent to the peak sunshine hours. If $\mathrm{k}$ photovoltaic modules are used in photovoltaic power plant, the standard performance ratio is calculated as follows:

$\mathrm{k}$

$$
\mathrm{PRstc}=\left(\mathrm{E} / \sum \mathrm{Ci} \times \mathrm{qiP} 0\right) /(\mathrm{Hi} / \mathrm{G})
$$

$\mathrm{i}=1$

Where $\mathrm{E}$ is the test period of photovoltaic power generation capacity, $\mathrm{Ci}$ is the temperature correction factor of the first component, $\mathrm{Hi}$ is the total amount of PV radiation for the i-type component testing cycle of, $P 0$ is the photovoltaic power station rated power, $G=1000 \mathrm{~W} / \mathrm{m} 2$. First the rated power of the components is calculated, and then temperature is corrected. The temperature correction coefficient of the i-th component is calculated as:

$$
\mathrm{Ci}=1+\delta \mathrm{i} \times(\text { Tcell-25) }
$$

Where $\delta \mathrm{i}$ is the power temperature coefficient of the $\mathrm{i}$-th PV module; Tcell is the average working temperature of the battery during the evaluation period.

If the PV plant has only one component, the standard performance ratio is calculated as follows:

$$
\mathrm{PRstc}=(\mathrm{E} /(\mathrm{C} \times \mathrm{P} 0)) /(\mathrm{H} / \mathrm{G})
$$

Two efficiency definitions can reflect the efficiency of photovoltaic power generation. The definition of the second definition will be given in the case analysis.

\section{Case Analysis}

The PV module conversion efficiency test is conducted in a distributed photovoltaic power plant A district 400kW sub-station in ShanDong Province. PV module conversion efficiency test, the inverter efficiency test and the photovoltaic power station efficiency test have been completed. $400 \mathrm{~kW}$ sub-station used the same type of PV modules, that is rated power of each panel is $250 \mathrm{Wp}$, the total area $\mathrm{A}$ of PV module nominal is $2560 \mathrm{~m} 2$. It is known that components $\alpha=+0.045 \% / \mathrm{k}, \beta=$ $-0.292 \%$ / k. Randomly selected the two components of the two tanks, three converters and three 
components of No. 3 Convergence box are conducted to test. According to the formula (1) (6) calculated as the results in Table 2 .

Table 2 PV Module Conversion Efficiency Test Results

\begin{tabular}{|c|c|c|c|c|c|c|c|}
\hline $\begin{array}{l}\text { Component } \\
\text { No. }\end{array}$ & $\begin{array}{l}\text { Measurement } \\
\text { s' times }\end{array}$ & $\begin{array}{l}\mathrm{T} 0 / \\
{ }^{\circ} \mathrm{C}\end{array}$ & $\begin{array}{l}\mathrm{G} /(\mathrm{W} \cdot \mathrm{m} \\
-2)\end{array}$ & $\begin{array}{l}\text { VMPP_T } \\
\text { EST/V }\end{array}$ & $\begin{array}{l}\text { IMPP_T } \\
\text { EST/A }\end{array}$ & $\begin{array}{l}\text { PMPP_S } \\
\text { TC/W }\end{array}$ & $\eta$ out \\
\hline \multirow[t]{2}{*}{$\begin{array}{l}\text { CABC114011 } \\
657 \mathrm{~A}\end{array}$} & 1 & 52.80 & 780.00 & 27.80 & 6.20 & 239.00 & $16.37 \%$ \\
\hline & 2 & 53.60 & 855.00 & 27.20 & 6.90 & 237.93 & $16.29 \%$ \\
\hline \multirow[t]{2}{*}{$\begin{array}{l}\text { CABC114011 } \\
683 \mathrm{~A}\end{array}$} & 1 & 58.4 & 943 & 26.6 & 7.5 & 232.29 & $15.91 \%$ \\
\hline & 2 & 58.2 & 950 & 26.6 & 7.6 & 233.53 & $15.99 \%$ \\
\hline \multirow[t]{2}{*}{$\begin{array}{l}\text { CABC114011 } \\
810 \mathrm{~A}\end{array}$} & 1 & 57.8 & 908 & 26.7 & 7 & 225.64 & $15.45 \%$ \\
\hline & 2 & 58 & 882 & 26.4 & 7 & 229.8 & $15.74 \%$ \\
\hline \multirow[t]{2}{*}{$\begin{array}{l}\text { CABC214005 } \\
38 \mathrm{~A}\end{array}$} & 1 & 60.6 & 985 & 25.9 & 8 & 232.33 & $15.91 \%$ \\
\hline & 2 & 61 & 980 & 25.9 & 8 & 233.76 & $16.01 \%$ \\
\hline \multirow[t]{2}{*}{$\begin{array}{l}\text { CABC114012 } \\
002 \mathrm{~A}\end{array}$} & 1 & 64.4 & 1000 & 25.5 & 8.2 & 233.26 & $15.98 \%$ \\
\hline & 2 & 64.4 & 1030 & 25.7 & 8.4 & 233.81 & $16.01 \%$ \\
\hline $\begin{array}{l}\text { CABC214004 } \\
904\end{array}$ & 1 & 62.2 & 869 & 26.2 & 7 & 234.06 & $16.03 \%$ \\
\hline
\end{tabular}

The test results show that the efficiency of components with the number CABC114011810A is low. The reasons included that the main components of the shadow dust, the loss of spectral fit, and the internal structure of the components. For inefficient components, further testing can be performed to reduce unnecessary power loss.

Case Analysis of Photovoltaic Inverter Efficiency Test. A total of 400kW sub-stations in a district of a distributed photovoltaic power station in Shandong Province were tested with four 100kW PV inverters. The test results of the SG-100K inverter were calculated according to the formula (7). The test results are shown in Table 3 , Where Pn is the rated power of the PV inverter, and Figure 4 shows the distribution of the efficiency of the inverter in full power.

Table 3 Photovoltaic Inverter Efficiency Test Results

\begin{tabular}{|l|l|l|l|l|l|l|l|l|}
\hline 功率点 & $10 \% \mathrm{Pn}$ & $20 \% \mathrm{Pn}$ & $30 \% \mathrm{Pn}$ & $40 \% \mathrm{Pn}$ & $50 \% \mathrm{Pn}$ & $60 \% \mathrm{Pn}$ & $70 \% \mathrm{Pn}$ & $80 \% \mathrm{Pn}$ \\
\hline$\eta$ & $95.83 \%$ & $97.23 \%$ & $97.77 \%$ & $98.08 \%$ & $98.32 \%$ & $98.32 \%$ & $97.78 \%$ & $97.71 \%$ \\
\hline
\end{tabular}

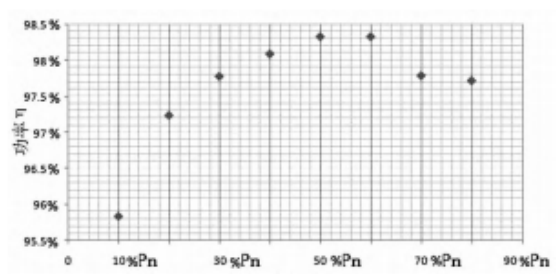

Figure 44 SG-100K inverter efficiency by power interval distribution map

From Table 3 and Figure 4 results show that in the $0 \sim 10 \%$ Pn power interval, the measured PV inverter efficiency average of $95.83 \%$, which in the entire power range is low, and $40 \% \mathrm{Pn} \sim 60 \% \mathrm{Pn}$ The power efficiency of the inverter is higher.

Case Study on Efficiency Test of Photovoltaic Power Plant. Grid voltage, current, power, component irradiance and other parameters are respectively tested in the field to test The test period is 3 days. According to the formulas (10) (11), the results are shown in Table 4, Tf is the actual power generation hours, $\mathrm{Tr}$ is the number of hours of the power generation. $\mathrm{Tf}=\mathrm{E} / \mathrm{P} 0, \mathrm{Tr}=\mathrm{H} / \mathrm{G}$, where $\mathrm{P} 0$ is the rated capacity of the photovoltaic power plant, $\mathrm{H}$ is the amount of radiation received, the 
temperature correction coefficient is $\mathrm{C}=0.972$, and the standard performance of the PV power station is $79.80 \%$.

Table 4 Photovoltaic Power Plant Efficiency Calculation Results

\begin{tabular}{|l|l|}
\hline Test Parameters & Test Results \\
\hline $\mathrm{Tf} / \mathrm{h}$ & 5.5 \\
\hline $\mathrm{Tr} / \mathrm{h}$ & 7.09 \\
\hline $\mathrm{C}$ & 0.972 \\
\hline PRstc & $79.80 \%$ \\
\hline
\end{tabular}

\section{Summary}

This paper elaborates the principle method of the efficiency test for the key links of the PV power plants including PV modules, inverters and power plants, and gives an example of the actual measurement of the power plants, which helps the PV owners to discover the equipment that caused the power generation low efficiency. Therefore they could maintain or replace it timely to ensure that the photovoltaic power plant is at a higher level of power generation efficiency and get better benefits.

\section{References}

[1] Tao Liu, Lusheng Zhou, Tao Wang, Liman Xu, Xiaoyu Zhang, Yu Wei, Lu Han. Hardware Circuit Design of PV Module Dust Detection System[J].. Industry and Technology Forum, 2017,07:37-39.

[2]Ling Cheng, Yan Tian, Yiming Li. Research on Harmonic Detection Method of Photovoltaic Power Generation System Based on CZT[J].. China Test, 2017,04:105-109.

[3]Changhui Qiu. An Active Frequency Offset Island Detection Method for Photovoltaic Power Generation[J].. Automation Technology \& Application,2016,10:100-103.

[4]Xiaokun Fang, Yuying An. Research on Maximum Power Point Tracking Method and Experimental Study of Photovoltaic Grid - connected Power Generation Based on Anti - mutation Load[J].. Electrical Measurement \& Instrumentation2017,03:19-24+30.

[5]Chengshan Yang, Yongxiang Cai, Xiaoyan Liu. Lightning Detection Method for Photovoltaic Power System[J]. Journal of Nanjing University of Information Science \&Technology (Natural Science Edition) ,2015,06:551-556. 